\title{
Responses of vegetation to a changing regime of disturbance: effects of feral pigs in a Californian coastal prairie
}

Post-print/Accepted manuscript

Peter M. Kotanen

Kotanen, P. M. (1995), Responses of vegetation to a changing regime of disturbance: effects of feral pigs in a Californian coastal prairie. Ecography, 18: 190-199. doi:10.1111/j.1600-0587.1995.tb00340.x

This is the peer reviewed version of the following article: Kotanen, P. M. (1995), Responses of vegetation to a changing regime of disturbance: effects of feral pigs in a Californian coastal prairie. Ecography, 18: 190-199, which has been published in final form at http://dx.doi.org/10.1111/j.1600-0587.1995.tb00340.x This article may be used for non-commercial purposes in accordance with Wiley Terms and Conditions for SelfArchiving.

\section{HOW TO CITE TSPACE ITEMS}

Always cite the published version, so the author(s) will receive recognition through services that track citation counts, e.g. Scopus. If you need to cite the page number of the TSpace version (original manuscript or accepted manuscript) because you cannot access the published version, then cite the TSpace version in addition to the published version using the permanent URI (handle) found on the record page. 


\section{RESPONSES OF VEGETATION TO A CHANGING REGIME OF DISTURBANCE: EFFECTS OF FERAL PIGS IN A CALIFORNIAN \\ COASTAL PRAIRIE}

Peter M. Kotanen, Dept of Integrative Biology, Univ. of California, Berkeley, CA 94720, USA. (Present address: Dept of Ecology and Evolution, Univ. of Chicago, 1101 E. 57th St., Chicago, IL 60637, USA). 


\section{Abstract}

Disturbance can eliminate sensitive native species and facilitate invasions by exotics, but disturbance is also important in the maintenance of many nativedominated ecosystems. Because of this dual role, disturbance can have complex implications for biodiversity. I have investigated the effects of an introduced agent of disturbance, the feral pig (Sus scrofa L.), in meadows in northern California. Pigs were the principal agent of soil disturbance at this site, annually overturning an average of $7.4 \%$ of the total surface area. Grubbed areas revegetated rapidly, but grubbing had significant effects on the composition of the affected vegetation. Species richness was reduced in grubbed plots in the first year following disturbance, but rose thereafter, often exceeding the richness of undisturbed controls. Disturbance did not exclusively benefit either native or exotic species. Changes in richness primarily reflected the early colonization of disturbed plots by natives, particularly annuals, although alien annual grasses also increased in disturbed sites. Consequently, though non-natives did respond positively to disturbance, at least in the short-term they did not simply replace natives. Pigs' effects may typify the complicated events to be expected when an ecosystem's regime of disturbance is significantly altered, either by direct human intervention or as a consequence of a biological invasion. 


\section{Introduction}

Disturbance can damage natural ecosystems both by suppressing sensitive species (Huston 1979, Sousa 1984, Pickett and White 1985, Petraitis et al. 1989) and by facilitating invasions by non-natives (Elton 1958, Mooney and Drake 1986, Drake et al. 1989, Pimm 1991, Hobbs and Huenneke 1992). However, natural disturbance also plays an important role in maintaining the species composition, diversity, and structure of many native-dominated ecosystems (Huston 1979, Sousa 1984, Pickett and White 1985, Petraitis et al. 1989, Hobbs and Huenneke 1992). Because of this dual role, the net effects of disturbance on the diversity of native species often may be complex and difficult to predict. Of special concern are changes from the historic disturbance regime (Hobbs and Huenneke 1992). Practices that increase the frequency of disturbance (e.g., logging, anthropogenic fire) and practices that decrease disturbance (e.g., fire suppression, exclusion of rivers from their floodplains) both may alter natural communities and ultimately erode biodiversity (Hobbs and Huenneke 1992).

Land management practices often have obvious and direct implications for disturbance regimes; however, humans also may change disturbance regimes indirectly by altering the abundance of "keystone" organisms. For example, the removal from and subsequent re-invasion of much of North America by beaver (Castor canadensis Kuhl) have had profound effects on rates of gap creation in forest ecosystems (Naiman et al. 1986, 1988, Johnson and Naiman 1990). Similarly, D'Antonio and Vitousek (1993) report cases in which invasions by exotic grasses have been implicated in increasing fire frequencies. In this paper, I report 
some of the ecological consequences of the introduction of an exotic agent of disturbance, the feral pig (Sus scrofa L.), into northern California, USA. I have documented rates of disturbance by pigs and consequences for the composition of meadow communities containing both native and alien plant species. The effects of feral pigs on plant assemblages have previously been reported from regions as diverse as the Appalachians (Bratton 1974, 1975, Howe et al. 1981), Hawai'i (Spatz and Mueller-Dombois 1975, Cooray and Mueller-Dombois 1981, Aplet et al.1991), and (with goats) subantarctic islands (Campbell and Rudge 1984), but this paper represents one of the first accounts of pigs' effects in California. The flora of this region has long been structured by frequent disturbances including annual summer drought, fires, and the activities of a variety of burrowing mammals. Lessons learned from wetter, cooler regions with histories of less frequent fire, or from islands with depauperate vertebrate faunas, may not apply (Denslow 1980, 1985, Hobbs and Huenneke 1992).

\section{Methods}

\section{The study site}

This study was conducted at the Northern California Coast Range Preserve (NCCRP) of the University of California (123 $37^{\prime} \mathrm{W}, 39^{\circ} 45^{\prime} \mathrm{N}$ ), about $240 \mathrm{~km}$ north of San Francisco. The dominant regional vegetation is Pseudotsuga menziesii (Mirbel) Franco - Sequoia sempervirens (D. Don) Endl. forest, but this report is concerned with a series of 5 meadows, ranging in size from 2 ha to 8 ha, at an elevation of about $400 \mathrm{~m}$. These meadows are believed to pre-date the arrival of the first homesteaders in the 1880's (Johnson 1979). Each meadow was 
subsequently grazed or cultivated, but agriculture ended by the 1930's as the homesteads successively failed (Johnson 1979).

Coincident with the arrival of European settlers, most Californian grasslands underwent great floristic changes. Many inland locations are thought originally to have been dominated by perennial bunchgrasses, which were largely replaced by Mediterranean annual grasses prior to 1900 (Heady 1988, Heady et al. 1988, Sims 1988, Heady et al. 1992). In contrast, coastal grasslands have fared comparatively well, and native perennial grasses often seem able to outcompete or coexist with annual invaders in coastal areas (Heady et al. 1988, 1992). Despite their past agricultural usage, most meadows at the NCCRP still contain Coastal Prairie vegetation, dominated both visually and in terms of biomass by the native bunchgrass Danthonia californica Bolander. Several other perennial graminoids (Gramineae, Cyperaceae, Juncaceae) occur at lower frequencies (Appendix I). Most of the common annual graminoids have been introduced (e.g., Aira caryophyllea L., Bromus hordaceus L., Briza minor L.), but the native Juncus bufonius L. and both native (V. microstachys (Nutt.) Benth.) and alien (V. bromoides (L.) S.F. Gray and $V$. myuros (L.) C. Gmelin) species of Vulpia are also encountered (Appendix I). Native perennial "bulbs" (primarily Dichelostemma capitatum Alph. Wood, rarely Brodiaea elegans Hoover, Triteleia hyacinthina (Lindley) E. Greene, and Triteleia laxa Benth., all of which technically produce corms) and numerous native and alien dicots also commonly occur (Appendix I).

\section{Feral pigs}

Pigs (Sus scrofa L.) are native to Eurasia and North Africa, but are also very 
widely distributed as feral animals. Currently, wild pigs are found on all continents except Antarctica; their non-native distribution includes parts of North and South America, Central America, Australia, New Zealand, New Guinea, South Africa, and many oceanic islands (Lever 1985). In areas where they are numerous, feral pigs can strongly affect vegetation (e.g., Bratton 1974, 1975, Howe et al. 1981; Kotanen 1994a); wild pigs also may play an important ecological role in the parts of their native Eurasian range where they still persist in sufficient numbers (Oliver and Fruzinski 1991).

Feral pigs have existed in California at least since the 1700's, and currently are common in many coastal and some inland counties (Barrett 1978, Wood and Barrett 1979, Lever 1985, Mayer and Brisbin 1991, Barrett 1993); their numbers have been increasing in recent decades (Barrett 1993). At the NCCRP, feral pigs may have arrived as settlers' domestic stock as early as the 1880's (Johnson 1979). Since the 1920 's, hybridization and stocking by hunters probably have added Wild Boar genotypes, as has occurred elsewhere in California (Pine and Gerdes 1973, Barrett 1978, Mayer and Brisbin 1991). Pigs have been protected from sport hunting since this property was acquired by the Nature Conservancy in 1959, and subsequent control efforts have been sporadic and ineffective. Consequently, the meadows described in this study have been influenced by pigs since the local cessation of agriculture. The current population size is unknown, but the preserve steward (P. Steel, pers. com.) regularly encounters groups of 7-8 and has seen herds of more than 20 animals.

\section{Patterns of grubbing}


Feral pigs are omnivorous, and a substantial proportion of their diet is obtained by grubbing in search of roots, bulbs, and other below-ground material (Pine and Gerdes 1973, Bratton 1974, Scott and Pelton 1975, Howe and Bratton 1976, Barrett 1978, Wood and Roark 1980, Howe et al. 1981, Grover 1983, Baber and Coblenz 1987). Grubbing by feral pigs is visually unmistakable. Grubbing entails breaking through the surface layer of vegetation, followed by excavation to a depth typically ranging between 5 and $15 \mathrm{~cm}$. The displaced vegetation and soil may be left in place, or may be moved slightly to the side, smothering otherwise intact vegetation. Severely grubbed areas may extend for a hectare or more, but typically are composed of many small $\left(\sim 1 \mathrm{~m}^{2}\right)$, overlapping disturbed patches ("feeding stations" - Vallentine 1990). Pig disturbance contrasts sharply with the discrete, regular mounds produced by moles, Scapanus latimanus Bachman, pocket gophers, Thomomys bottae Eydoux \& Gervais, ground squirrels, Spermophilus beecheyi Richardson, and ants; these animals also tend to bury, rather than disrupt, the surface vegetation. Grubbing is not usually associated with yellowjacket (Vespula sp.) nests, as is the case for the diggings of skunks (Mephitis mephitis Schreber). Other than humans and the now-extirpated grizzly (Ursus arctos L.), no other Californian animal disturbs soil in the distinctive "rototilling" fashion of pigs.

Beginning in October 1990, grubbing was quantified annually along a series of transects in each of 5 meadows. The transects of each series were parallel and aligned at right angles to the long axis of their meadow. Transects were separated by $20 \mathrm{~m}$ in the White House Meadow (total of 15 transects, averaging $164 \mathrm{~m}$ in length) and by $40 \mathrm{~m}$ in the other 4 meadows (5-8 transects/meadow, averaging 
$101 \mathrm{~m}$ in length). On the first sampling of the White House Meadow, the proportion of the ground area recently (within the last year) disturbed by pigs was visually estimated in contiguous $1 \mathrm{~m} \times 1 \mathrm{~m}$ quadrats laid along each transect. At all other samplings, a point-intercept method was used: the presence or absence of recent ( $<1$ year old) pig damage was noted at $1 \mathrm{~m}$ intervals along measuring tapes. Recent damage was identified by a loose soil surface and a sparsity of colonizing plants.

\section{Revegetation of grubbed areas}

In November 1990, a set of thirty 25 x $25 \mathrm{~cm}$ permanent plots was established in the White House Meadow, in an area which had been patchily disturbed by pigs. Ten of these plots were positioned in randomly-chosen locations which pigs had excavated (pre-existing vegetation removed, soil surface depressed), and 10 in random locations which pigs had buried beneath overturned earth (pre-existing vegetation present beneath a layer of displaced soil, soil surface elevated). The remaining 10 (control) plots were interspersed in randomly-chosen patches of undisturbed vegetation. All 30 plots were then fenced to protect them from further grubbing. The exact date on which this area had been disturbed is unknown, but it appeared to have been grubbed during the winter of 1989-1990.

In June 1991, another set of 30 plots was established in each of 2 additional meadows (Upper Walker and Lower Walker), in areas that had been patchily grubbed in the winter of 1990-1991. Half of these plots were placed in randomlychosen pig-damaged locations, while half were interspersed in undamaged areas. Buried and excavated plots were not treated separately, since grubbing at these sites had been so thorough as to make this distinction arbitrary, and these plots 
were left unfenced for reasons of economy.

Beginning in June 1991, all plots were sampled annually in late spring or early summer, after most species had flowered but before most spring ephemerals had vanished. At each sampling, the identities of the vascular plant species in each plot were noted. The proportion of species that were annuals was calculated, as was the proportion comprised by aliens, based on data derived from Hickman (1993). Species richness ( $\square$ diversity) was analyzed using untransformed data, while proportions were arcsin transformed before analysis (Sokal and Rohlf 1981). Data from the White House Meadow were analyzed by ANOVA, followed by protected Tukey HSD tests (Sokal and Rohlf 1981); data for the other meadows were analyzed by $t$-test. Those data failing to pass the $\mathrm{F}_{\max }$ test for homogeneity of variance were analyzed using t-tests for unequal variances (Sokal and Rohlf 1981).

\section{Results}

\section{Patterns of grubbing}

Most grubbing occurred from mid-autumn to early spring, probably reflecting the Mediterranean pattern of rainfall: the dense soils of these meadows are soft when moist, but become extremely hard after the rains end in the spring. Some of the most extensive grubbing during this study occurred after heavy winter rains, particularly as a multiyear drought ended in the winter of 1992-1993.

Pigs were the predominant agent of soil disturbance during this study. Between 1990 and 1993, transects indicated that pigs annually grubbed an average of $7.4 \%$ of the area of the 5 study meadows (mean calculated by pooling all data; see Figure 1). In contrast, all native animals together (including moles, pocket 
gophers, ground squirrels, skunks, and ants) annually disturbed much less than $1 \%$. This latter figure may be an underestimate, since pig damage may have been superimposed on other forms of soil disturbance. The magnitude of this bias should have been very small however, both since $92.6 \%$ of the area was not pigdisturbed, and since at least pocket gophers (which burrow deeper than all but the most severe grubbing) generally survived to created new mounds in pig-disturbed areas. Because of the subsequent change of methods, data from the first sampling date should be treated with caution; however, the estimate obtained on this date (11.0\% damaged) was close to the overall mean, suggesting that any bias may have been small.

All meadows were grubbed to some extent each year. While some meadows tended to suffer more than others, no one meadow was consistently the most damaged (Figure 1). For example, Upper Walker Meadow was heavily grubbed in the the winters of 1989-1990 (P.M. Kotanen, pers. obs.), 1990-1991 and 19921993, but was almost untouched in 1991-1992. Most damage apparently occurred in only a few episodes per year, suggesting that a few mobile herds may have been responsible. Differences between years may simply represent chance variations in the movements of pigs.

Within each meadow, grubbing was a very patchy phenomenon; large regions were often devastated while the remainder of the meadow was left practically untouched. Pigs damaged some areas more frequently than chance alone would suggest. For example, of the 30 monitoring plots established in damaged patches in the Upper and Lower Walker Meadows, 29 were re-grubbed 
and destroyed in just 2 years. In some cases, grubbing was associated with some physical feature (usually damp ground or seeping water), or with the presence of a plant (e.g., bulb-bearing species such as Brodiaea, Dichelostemma, Triteliaea, and Zigadenus), but most commonly the resource that motivated the grubbing was obscure. Pigs may often grub in search of soil animals (Grover 1983) or simply in response to easily workable soil.

\section{Revegetation of grubbed areas}

Grubbing removed or buried most surface vegetation, and disturbed soil to a depth of several $\mathrm{cm}$ (mean $=7.0 \mathrm{~cm}, \mathrm{SEM}=0.2 \mathrm{~cm}$, based on 86 comparisons with nearby undisturbed surfaces). Nonetheless, most $25 \mathrm{~cm} \times 25 \mathrm{~cm}$ plots contained survivors. In particular, Danthonia californica occurred as either survivors or seedlings in $82 \%$ of all disturbed plots within their first year, as opposed to $87 \%$ of control plots (percentages calculated with all meadows weighted equally). Bulbs of Dichelostemma capitatum and similar species also were common survivors in recently-grubbed areas, occurring in 53\% of disturbed plots and $51 \%$ of control plots (all meadows weighted equally). When present, bulbs could be very abundant, numbering up to 200 per $10 \mathrm{~cm} \times 10 \mathrm{~cm}$ quadrat in undisturbed areas.

Overall, more than 50 species were observed in at least one monitoring plot (Appendix I). A few nonflowering or problematic species could not always be distinguished, but this should not have led to significant biases for two reasons. First, since the monitoring plots were small, the probability of two indistinguishable species appearing in the same plot should also be small; thus, 
lumping similar species probably rarely led to underestimates of species richness. Second, even if a species' identity was uncertain, its life history and origins usually could be determined by observation or from information in Hickman (1993) and Stebbins (1968). Vulpia, which locally includes both aliens and natives, was the only truly problematic genus. All members of this genus of annuals were treated as a single alien species; neither patterns of significance nor the ranking of treatment means changed if this genus was instead treated as native.

Depending on the site, $70 \%-80 \%$ of the observed species occurred in both grubbed and undisturbed plots; most of the remainder were rare (1 or 2 occurrences). In the Upper and Lower Walker Meadows, species richness was significantly reduced (relative to the undisturbed controls) in the first spring following grubbing (Figure 2). In contrast, the average richness of disturbed plots significantly exceeded that of the controls by the second year (Figure 2). Most plots were destroyed by pigs before their third sampling. Data from the few that survived are consistent with richness remaining as great or greater in grubbed areas (Figure 2). Results from the White House Meadow are more difficult to interpret, in part because of the uncertainty as to when the grubbing at this site had occurred: plots in this meadow may have been grubbed up to a year earlier than plots in the Walker Meadows. Nonetheless, trends in the White House Meadow qualitatively resembled those in the Walker Meadows. Richness tended to be reduced by grubbing at the first sampling, though this result was marginally nonsignificant ( $\mathrm{p}=0.059)$ (Figure 2). At the second and third samplings, richness tended to be lowest in the undisturbed controls, though differences among 
treatments were again small and nonsignificant (Figure 2).

In all meadows, changes in richness between years were largely attributable to the invasion of disturbed plots by annual graminoids and herbs (Figure 3). At the first sampling, the proportion of species in disturbed plots that was made up by annuals did not vary significantly among treatments, though it tended to be reduced in the Walker Meadows. At subsequent samplings, the average proportion of annuals always was highest in disturbed plots, though this difference rarely was significant (Figure 3). The species most conspicuously associated with grubbed areas were mostly natives (e.g., Eremocarpus setigerus (Hook.) Benth., Navarretia spp., and Juncus bufonius). As a result, the average contribution by aliens to species richness was lower in disturbed plots than in controls (Figure 4), excepting the final sampling for the Upper Walker Meadow, when only one grubbed plot still survived. Differences among treatments frequently were significant on the first sampling date, but had diminished to nonsignificance by the second (Figure 4). The numerical abundance of colonizing species did not necessarily show the same trends as species richness. In particular, introduced grasses (especially Aira caryophyllea) frequently became very abundant in grubbed plots. Aira also strongly benefitted from some types of experimental soil disturbances, and increased to a lesser extent even in undisturbed controls during this study (Kotanen 1994b).

Three lines of evidence suggest that sample sizes generally were adequate. First, though the total number of species detected for each date $\mathrm{x}$ site $\mathrm{x}$ treatment combination usually continued to rise as long as sample size increased, running 
averages (Greig-Smith 1983) indicated that estimates of the mean species richness per plot, the mean proportion of annuals, and the mean proportion of aliens all rapidly stabilized as sample sizes increased. Of the 51 estimates based on sample sizes $\square$, only 7 were not within $10 \%$ of the final value by just the 5 th sample. Second, the values estimated for the mean proportions of annuals and aliens at each site (Figures 2-4) generally clustered around the values obtained from the species pool as a whole (64\% annuals and $40-42 \%$ aliens, depending on the treatment of Vulpia - Appendix I). Finally, significant differences among treatments were detected at least once at each site and for each variable, indicating that sufficient statistical power was available.

\section{Discussion}

Feral pigs dominate the disturbance regime at this location; this result contrasts with other studies of Californian grasslands (e.g., Hobbs and Mooney 1985) in which native animals such as pocket gophers were the principal source of soil disturbance, but probably is typical of sites where pigs are common. Nonetheless, native annuals and perennials both were abundant, and persisted or even increased in pig-disturbed areas. Alien annuals also colonized disturbed sites, but not in sufficient numbers to exclude opportunistic natives. Most of these results can be understood by considering the history of the local flora and the regeneration strategies of both annual and perennial colonists.

The course of revegetation in pig-disturbed areas broadly resembled the results of other studies which have found grasslands and old-fields to contain guilds of competitively-inferior or fugitive species able rapidly to exploit 
disturbance (e.g., Platt 1975, Platt and Weis 1977, Gross 1980, Gross and Werner 1982, Armesto and Pickett 1985, Hobbs and Mooney 1985, Martinsen et al. 1990, Lavorel et al. 1994). At this location, most of the species that quickly occupied disturbed areas were annuals. While some (notably Juncus bufonius) were present in the seedbank (Kotanen 1994b), many probably arrived in the seed rain, explaining why species richness failed to rise until the second year following disturbance: seed dispersal essentially has ended by the time that both rainfall and grubbing begin in the autumn (Kotanen 1994b). A few of these annuals may have been disturbance-dependent fugitives (sensu Platt 1975, Platt and Weis 1977), but most were also frequent in undisturbed vegetation, and consequently do not seem strictly to depend upon grubbing. Juncus bufonius was the most notable exception. This annual native rush was common in grubbed areas, but almost never was observed on undisturbed soil. Weedy annuals may be less dependent upon soil disturbance in Californian grasslands than in many perennial-dominated habitats, since the gaps between bunchgrasses and the yearly dieback of annuals provide unoccupied space even in the absence of soil disturbance (q.v. Grubb 1986 for a similar discussion of "matrix-forming perennials" and "interstitial short-lived plants" in chalk grassland).

Long-lived perennials might be expected to be suppressed by frequent disturbance, yet Danthonia dominates these meadows after more than a century of grubbing, grazing, and cultivation (Johnson 1979). Even on the small scale of a $25 \mathrm{x}$ $25 \mathrm{~cm}$ plot, pigs rarely eliminated this bunchgrass from grubbed areas, and its seedlings were common in disturbed sites. Survivors and seedlings were able to 
expand by vegetative growth for up to a year before the seeds of annuals arrived; consequently, disturbance may even have created an "establishment window" for this species (Lavorel et al. 1994). Likewise, perennial bulbs including Dichelostemma, Brodiaea, and Triteleia remain abundant in most meadows, even though members of these genera are preferred foods (Barrett 1978 and pers. com.). The explanation may be that they produce large numbers of tiny $(2 \mathrm{~mm})$ vegetative bulblets which probably are difficult for pigs to handle, and instead may be dispersed by grubbing. Anderson (1992) has suggested these bulblets similarly were key to the sustainable harvest of these species by Native Americans. Other studies also have indicated that not all bulbs are vulnerable to pigs. In the Appalachians, the effects of grubbing by Wild Boar ranged from severe reductions of some bulbs (e.g., Lilium superbum L. - Bratton 1974) to mild or transient effects on others (e.g., Claytonia virginica L. and Erythronium americanum Ker. - Bratton 1974, Howe et al. 1981, Bratton et al. 1982).

Disturbance often is predicted to in facilitate invasions by alien species $(e . g$., Elton 1958, Mooney and Drake 1986, Drake et al. 1989, Pimm 1991, Hobbs and Huenneke 1992), yet disturbance by agents such as grazing, fire and burrowing animals is also a natural characteristic of most grasslands (Sousa 1984, Goldberg and Gross 1988, Hobbs and Huenneke 1992). It follows that a subset of native plants should be adapted to disturbance (Denslow 1980, Hobbs and Huennecke 1992). Consequently, despite the unique appearance of pig-created soil disturbance, perhaps it should not be surprising that both natives and aliens colonized grubbed areas. The predominance of natives among the first invaders of 
disturbed plots reflected the great diversity of opportunistically weedy native annuals in the local flora (Appendix I), as well as the ability of native perennials to survive disturbance; both may be consequences of a long regional history of frequent disturbance and annual diebacks. However, considering abundance instead of species richness suggests somewhat different conclusions, since a few introduced annual grasses (notably Aira) often became dominant in disturbed plots after their seeds began to arrive. Consequently, whether pigs are seen as enhancing or reducing biodiversity depends to some extent on the measure used. If one is concerned with maintaining the native component of species richness, pigs might seem to benefit grasslands by creating habitat for uncompetitive native species (q.v. Grubb 1977, Connell 1978, Huston 1979, Sousa 1979, 1984, Denslow 1985, Petraitis et al. 1989, Lavorel et al. 1994). Pigs might even act as a partial substitute for the effects of natural wildfires, which now are effectively suppressed. In contrast, if one is concerned with maintaining evenness, species composition, or vegetation structure, pigs might be seen as harmful.

The composition of Californian annual grasslands varies strongly from year to year, primarily in response to weather (Heady 1956, 1958, Pitt and Heady 1978, Bartolome 1989, Hobbs and Mooney 1991, Heady et al. 1992). For example, workers in annual grasslands have reported "grass", "filaree" (Erodium spp.) and "clover" (legume) years, which apparently result from particular combinations of amount and timing of rainfall and winter temperatures (Heady et al. 1992 ). As might be expected, different species respond to weather in distinctly different ways (e.g., Pitt and Heady 1978), making generalization very difficult. However, it 
is likely that dry years can suppress native perennial grasses, which tend to be less xerophytic than many invasive annual species (Bartolome et al. 1980, Heady et al. 1992), and can simultaneously reduce litter production to the ultimate benefit of prolific but litter-intolerant annuals such as Aira (Heady 1956, J. Bartolome, pers. com.). The experiments described in this paper were conducted near the end of a 6-year drought, which apparently did lead to large increases in the numbers of some alien annual grasses, notably Aira (Kotanen 1994b). These changes may have been amplified on pig-disturbed soil: Hobbs and Mooney (1991) found that the vegetation colonizing gopher mounds was more sensitive to rainfall variation than was undisturbed annual grassland. Since all experimental plots experienced the same weather, climatically-driven changes alone cannot explain the differences observed among treatments at a single sampling. However, if the drought increased the dominance of alien annual grasses on pig disturbances above the levels typical of a wet year, these experiments may have overestimated the longterm average success of alien grasses in grubbed areas. This interpretation would strengthen at least one major conclusion: the failure of alien annuals to monopolize pig-created disturbances might have been even greater in the presence of "normal" patterns of rainfall.

These results should not be interpreted as evidence that pig-created disturbances are environmentally benign. First, any truly pig-sensitive species may have been eliminated from this location decades before this study began. Second, grubbing creates large amounts of open space, reduces perennial cover, and encourages alien annual grasses as well as native herbs. Disturbed areas 
eventually may be occupied by vegetation resembling the pre-existing assemblage, but pigs still are responsible for maintaining a substantial portion of these meadows in a chronically disturbed state, and may grub some areas so frequently as to make long-term successional trends irrelevent. Finally, pigs' effects may be even more pronounced in plant assemblages lacking native perennials as resilient as Danthonia and Dichelostemma, at sites threatened by aggressively invasive alien weeds, and in regions with less of a history of disturbance by pigs, fire, drought, or other agents. This may help to explain why many studies at other locations have demonstrated that pigs can severely harm native plant assemblages (e.g., Bratton 1974, 1975, Howe et al. 1981, Spatz and Mueller-Dombois 1975, Cooray and Mueller-Dombois 1981, Tisdell 1982, Campbell and Rudge 1984, Peart 1993). Pigs may be representative of many agents of disturbance, in that their effects are dependent upon the biology and disturbance history of the affected community (Denslow 1980, 1985, Hobbs and Huenneke 1992).

Acknowledgements - I would like to thank L. Ambedian, R. Barrett, F.S. Chapin III, M. Gleason, R. Hufbauer, C. Pfister, M. Poteet, M. Power, C. Purrington, W. Sousa, and two anonymous reviewers for their contributions to my research and this manuscript. Funding was provided by an NSF Doctoral Dissertation Improvement Grant (DEB-9122821), an NSERC Postgraduate Fellowship, the Nature Conservancy of California (CARO 042491-K), a Mildred E. Mathias Grant of the University of California Natural Reserve System, the Hardman Foundation, and the 
Department of Integrative Biology at U.C. Berkeley.

\section{References}

Anderson, K. 1992. At home in the wilderness. - News from Native California 6 (supplement): 3-5.

Aplet, G. H., Anderson, S. J. and Stone, C. P. 1991. Association between feral pig disturbance and the composition of some alien plant assemblages in Hawaii Volcanoes National Park. - Vegetatio 95: 55-62.

Armesto, J. J. and Pickett, S. T. A. 1985. Experiments on disturbance in old-field communities: impact on species richness and abundance. - Ecology 66: 230240.

Baber, D. and Coblenz, B. 1987. Diet, nutrition, and conception in feral pigs on Santa Catalina Island. - J. Wildl. Manage. 51: 306-317.

Barrett, R. H. 1978. The feral hog on the Dye Creek Ranch, California. - Hilgardia 46: 282-355.

- 1993. Feral swine: The California experience - In: Hanselka, C. W. and Cadenhead, J. F. (eds), Feral swine: A compendium for resource managers. Texas Agricultural Extension Service, Corpus Christi, TX, pp 107-116.

Bartolome, J. W. 1989. Local temporal and spatial structure. - In: Huennecke, L. F. and Mooney, H. (eds), Grassland structure and function: California annual grassland. Kluwer Academic Publishers, Dordrecht, The Netherlands, pp 7380.

-, Stroud, M. C. and Heady, H.F. 1980. Influence of natural mulch on forage production on differing California annual range sites. J. Range Manage. 33: 4- 
8.

Bratton, S. 1974. The effect of the European Wild Boar (Sus scrofa) on the highelevation vernal flora in the Great Smoky Mountains National Park. - Bull. Torrey Bot. Club 101: 198-206.

- 1975. The effect of the European Wild Boar, Sus scrofa, on Gray Beech forest in the Great Smoky Mountains. - Ecology 56: 1356-1366.

-, Harmon, M. and White, P. 1982. Patterns of European Wild Boar rooting in the western Great Smoky Mountains. - Castanea 47: 230242.

Campbell, D. J. and Rudge, M. R. 1984. Vegetation changes induced over ten years by goats and pigs at Port Ross, Auckland Islands (subantarctic). - N. Z. J. Ecol. 7: 103-118.

Connell, J. H. 1978. Diversity in tropical rain forests and coral reefs. - Science 199: 1302-1310.

Cooray, R. G. and Mueller-Dombois, D. 1981. Feral pig activity. - In: MuellerDombois, D, Bridges, K. W. and Carson, H. L. (eds), Island ecosystems: biological organization in selected Hawaiian communities (US/IBP Synthesis Series 15). Hutchinson Ross Publishing Company, Stroudsburg, PA, pp. 309317.

D'Antonio, C. M. and Vitousek, P.M. 1992. Biological invasions by exotic grasses, the grass/fire cycle, and global change. - Ann. Rev. Ecol. Sys. 23: 63-87.

Denslow, J. S. 1980. Patterns of plant species diversity during succession under different disturbance regimes. - Oecologia 46: 1821.

- 1985. Disturbance-mediated coexistence of species. - In: Pickett, S. T. A. and White, 
P. S. (eds), The ecology of natural disturbance and patch dynamics. Academic Press, Orlando, FL, pp. 307-323.

Drake, J. A., Mooney, H. A., di Castri, F., Groves, R. H., Kruger, F. J., Rejmanek, M. and Williamson, M. (eds). 1989. Biological invasions: A global perspective (SCOPE 37). John Wiley \& Sons, Chichester, UK.

Elton, C. S. 1958. The ecology of invasions by plants and animals. Chapman and Hall, London, England.

Goldberg, D. E. and Gross, K. L. 1988. Disturbance regimes of midsuccessional old fields. - Ecology 69: 1677-1688.

Greig-Smith, P. 1983. Quantitative plant ecology (third edition). Blackwell Scientific Publications, Oxford, England.

Gross, K. L. 1980. Colonization by Verbascum thapsus (Mullein) of an old-field in Michigan: Experiments on the effects of vegetation. - J. Ecol. 68: 919-927.

- and Werner, P. A. 1982. Colonizing abilities of "biennial" plant species in relation to ground cover: implications for their distributions in a successional sere. - Ecology 63: 921-931.

Grover, A. 1983. The home range, habitat utilization, group behavior, and food habits of the feral hog (Sus scrofa) in northern California. - Thesis, California State University, Sacramento, CA, USA.

Grubb, P. J. 1977. The maintenance of species-richness in plant communities: the importance of the regeneration niche. - Biol. Rev. 52: 107-145.

- 1986. Problems posed by sparse and patchily distributed species in species-rich plant communities. - In: Diamond, J. and Case, T. J. (eds), Community ecology. Harper 
and Row, New York, NY, pp. 207225.

Heady, H. F. 1956. Changes in a California annual plant community induced by manipulation of natural mulch. Ecology 37: 798-812.

- 1958. Vegetational changes in the California annual type. Ecology 39: 402-416.

- 1988. Valley grassland. - In: Barbour, M. G. and Major, J. (eds), Terrestrial vegetation of California (new expanded edition). Wiley, New York, NY, pp 491-514.

-, Foin, T. C., Kektner, J. J., Taylor, D. W., Barbour, M. G. and Berry, W. J. 1988. Coastal prairie and northern coastal scrub. - In: Barbour, M. G. and Major J. (eds), Terrestrial vegetation of California (new expanded edition). Wiley, New York, NY, pp. 733-760.

-, Bartolome, J. W., Pitt, M. D., Savelle, G. D. and Stroud, M. C. 1992. California prairie. - In: Coupland, R. T. (ed), Ecosystems of the world 8A: Natural grasslands. Elsevier, Amsterdam, pp. 313-335

Hickman, J. C. (ed). 1993. - The Jepson manual: Higher plants of California. University of California Press, Berkeley, CA.

Hobbs, R. J. and Huenneke, L. F. 1992. Disturbance, diversity, and invasion: implications for conservation. - Conserv. Biol. 6: 324337.

- and Mooney, H. 1985. Community and population dynamics of serpentine grassland annuals in relation to gopher disturbance. - Oecologia 67: 342-351.

- and Mooney, H. 1991. Effects of rainfall variability and gopher disturbance on serpentine annual grassland dynamics. Ecology 72: 59-68.

Howe, T. and Bratton, S. 1976. Winter rooting activity of the European Wild Boar in the Great Smoky Mountains National Park. - Castanea 41: 256-264. 
-, Singer, F. and Ackerman, B. 1981. Forage relationships of European Wild Boar invading northern hardwood forest. - J. Wildl. Manage. 45: 748-754.

Huston, M. 1979. A general hypothesis of species diversity. - Am. Nat. 113: 81-101.

Johnson, S. 1979. The land-use history of the Coast Range Preserve, Mendocino County, California. - Thesis, San Francisco State University, San Francisco, CA. Johnston, C.A. and Naiman, R. J. 1990. Aquatic patch creation in relation to beaver population trends. Ecology 71: 1617-1621.

Kotanen, P. M. 1994a. Effects of feral pigs on grasslands. - Fremontia 22(2): 14-17.

- 1994b. Revegetation of meadows disturbed by feral pigs (Sus scrofa L.) in Mendocino County, California. - Thesis, University of California, Berkeley, California, USA.

Lavorel, S., Lepart, J., Debussche, M., Lebreton, J-D, and Beffy, J-L. 1994. Small scale disturbances and the maintenance of species diversity in Mediterranean old fields. Oikos 70: 455-473.

Lever, C. 1985. - Naturalized mammals of the world. Longman, London, UK. Martinsen, G. D., Cushman, J. H. and Whitham, T. G. 1990. Impact of pocket gopher disturbance on plant species diversity in a shortgrass prairie community. Oecologia 83: 132-138.

Mayer, J. J. and Brisbin I. L. Jr. 1991. - Wild pigs in the United States. The University of Georgia Press, Athens, GA.

Mooney, H. A. and Drake, J. A. (eds). 1986. - Ecology of biological invasions of North America and Hawaii. Springer-Verlag, New York, NY.

Naiman, R. J., Melillo, J. M. and J. E. Hobbie. 1986. Ecosystem alteration of boreal 
forest streams by beaver (Castor canadensis). - Ecology 67: 1254-1269.

-, Johnston, C. A. and Kelley, J. C. 1988. Alteration of North American streams by beaver. Bioscience 38: 753-762.

Oliver, W. L. R. and Fruzinski, B. 1991. Les porcs et l'homme / People and pigs. - In: Barrett, R.H. and F. Spitz, Biology of Suidae. IRGM, France, pp. 93-116

Peart, D. 1993. Impact of feral pig activity on vegetation composition associated with Quercus agrifolia on Santa Cruz Island, California - In: W. Tietje and R.H. Barrett (eds), The wild pig in California oak woodland: ecology and economics. Integrated Hardwood Range Management Program, Department of Forestry and Resource Management, University of California, Berkeley, CA, pp. 12-13.

Petraitis, P. S., Latham, R. E. and Niesenbaum, R. A. 1989. The maintenance of species diversity by disturbance. - Q. Rev. Biol. 64: 393-418.

Pickett, S. T. A. and White, P. S. (eds). 1985. - The ecology of natural disturbance and patch dynamics. Academic Press, Orlando, FL.

Pimm, S. 1991. - The balance of nature? University of Chicago Press, Chicago, IL.

Pine, D. and Gerdes, G. 1973. Wild pigs in Monterey County, California. - Calif. Fish Game 59: 126-137.

Pitt, M. D. and Heady, H. F. 1978. Responses of annual vegetation to temperature and rainfall patterns in northern California. Ecology 59: 336-350.

Platt, W. J. 1975. The colonization and formation of equilibrium plant associations on badger disturbances in a tall-grass prairie. - Ecol. Monog. 45: 285-305. - and Weis, I. M. 1977. Resource partitioning and competition within a guild of 
fugitive prairie plants. - Am. Nat. 111: 479-513.

Ray, J. C. 1988. Wild pigs in California: A major threat in California. - Fremontia 16(1): 3-8.

Scott, C. D. and Pelton, M. R. 1975. Seasonal food habits of the European wild hog in the Great Smoky Mountains National Park. - Proceedings of the Southeastern Association of Game and Fish Commissioners 28: 585-593.

Sims, P. L. 1988. Grasslands. - In: Barbour, M.G. and Billings, W.D. (eds), North American terrestrial vegetation. Cambridge University Press, Cambridge, UK, pp. 265-286.

Singer, F., Swank, W. and Clebsch, E. 1984. Effects of wild pig rooting in a deciduous forest. - J. Wildl. Manage. 48: 464-473.

Sokal, R. R. and Rohlf, F. J. 1981. - Biometry (second edition). W.H. Freeman and Company, New York, NY.

Sousa, W. P. 1979. Disturbance in marine intertidal boulder fields: the nonequilibrium maintenance of species diversity. - Ecology 60: 1225-1239.

- 1984. The role of disturbance in natural communities. - Ann. Rev. Ecol. Sys. 15: 353-391.

Spatz, G. and Mueller-Dombois, D. 1975. Succession patterns after pig digging in grassland plant communities on Mauna Loa, Hawaii. - Phytocoenologia 3: 346-373.

Stebbins, G. L. 1968. Preliminary list of the vascular plants found on the Northern California Coast Range Preserve, Nature Conservancy. - Ecological Studies Leaflet 14. The Nature Conservancy, Washington D.C. 
Tisdell, C. A. 1982. - Wild pigs: Environmental pest or economic resource? Permagon Press, Sydney, Australia.

Vallentine, J. F. 1990. - Grazing management. Academic Press, San Diego, CA.

Wood, G. and Barrett, R. H. 1979. Status of wild pigs in the United States. - Wildl. Soc. Bull. 7: 237-246.

- and Roark, D. N. 1980. Food habits of feral hogs in coastal South Carolina. - J. Wildl. Manage. 44: 506-511. 
Appendix I. Vascular plant species present (+) or absent (-) in monitoring plots in each of the three study meadows. Also indicated are life history and origins of each species. Nomenclature follows Hickman (1993); data are derived from the same source or by personal observation.

\begin{tabular}{|c|c|c|c|c|c|}
\hline Species & $\begin{array}{c}\text { Life } \\
\text { History }\end{array}$ & Origins & $\begin{array}{l}\text { White } \\
\text { House }\end{array}$ & $\begin{array}{l}\text { Lower } \\
\text { Walker }\end{array}$ & $\begin{array}{l}\text { Upper } \\
\text { Walker }\end{array}$ \\
\hline \multicolumn{6}{|l|}{ Graminoids } \\
\hline Aira caryophyllea L. & Annual & Introduced & + & + & + \\
\hline Briza minor L. & Annual & Introduced & + & + & + \\
\hline Bromus hordaceus L. & Annual & Introduced & + & + & + \\
\hline Bromus diandrus Roth. & Annual & Introduced & - & + & + \\
\hline Bromus carinatus Hook. \& Arn. & Perennial & Native & - & + & + \\
\hline Carex sp. & Perennial & Native & - & + & + \\
\hline Cynosurus echinatus L. & Annual & Introduced & - & + & + \\
\hline Dactylis glomerata L. & Perennial & Introduced & - & - & + \\
\hline Danthonia californica Bolander & Perennial & Native & + & + & + \\
\hline $\begin{array}{l}\text { Gastridium ventricosum (Gouan) } \\
\text { Schinz \& Thell. }\end{array}$ & Annual & Introduced & - & + & - \\
\hline Hordeum sp. & Perennial & Native & - & - & + \\
\hline Juncus bufonius L. & Annual & Native & + & + & + \\
\hline Juncus effusus L. & Perennial & Native & - & - & + \\
\hline Luzula comosa E. Meyer & Perennial & Native & + & - & - \\
\hline Poa pratensis $\mathrm{L}$. & Perennial & Introduced & - & - & + \\
\hline Vulpia spp. & Annual & Various & + & + & + \\
\hline \multicolumn{6}{|l|}{ Herbs } \\
\hline Achillea millefolium L. & Perennial & Native & - & + & - \\
\hline $\begin{array}{l}\text { Agoseris grandiflora (Nutt.) E. } \\
\text { Greene }\end{array}$ & Perennial & Native & + & - & + \\
\hline Anagallis arvensis L. & Annual & Introduced & - & - & + \\
\hline $\begin{array}{l}\text { Aphanes occidentalis (Nutt.) } \\
\text { Rydb. }\end{array}$ & Annual & Native & - & + & + \\
\hline Cerastium glomeratum Thuill. & Annual & Introduced & + & + & + \\
\hline $\begin{array}{l}\text { Clarkia purpurea (Curtis) Nelson } \\
\text { \& J.F. Macbr. }\end{array}$ & Annual & Native & + & + & + \\
\hline Convolvulus arvensis L. & Perennial & Introduced & - & + & - \\
\hline
\end{tabular}


Appendix I (continued)

\begin{tabular}{|c|c|c|c|c|c|}
\hline Species & $\begin{array}{c}\text { Life } \\
\text { History }\end{array}$ & Origins & $\begin{array}{l}\text { White } \\
\text { House }\end{array}$ & $\begin{array}{l}\text { Lower } \\
\text { Walker }\end{array}$ & $\begin{array}{l}\text { Upper } \\
\text { Walker }\end{array}$ \\
\hline $\begin{array}{l}\text { Dichelostemma capitatum Alph. } \\
\text { Wood }{ }^{*}\end{array}$ & Perennial & Native & + & - & + \\
\hline $\begin{array}{l}\text { Eremocarpus setigerus (Hook.) } \\
\text { Benth. }\end{array}$ & Annual & Native & + & + & + \\
\hline Erodium cicutarium (L.) L'Her. & Annual & Introduced & - & + & - \\
\hline Eschscholtzia californica Cham. & Perennial & Native & + & + & - \\
\hline Galium sp. & Annual & Introduced & - & + & + \\
\hline Geranium dissectum L. & Annual & Introduced & - & + & + \\
\hline Githopsis specularoides Nutt. & Annual & Native & - & - & + \\
\hline $\begin{array}{l}\text { Hesperevax sparsiflora (A. Gray) } \\
\text { E. Greene }\end{array}$ & Annual & Native & + & - & - \\
\hline Hypochaeris glabra L. & Annual & Introduced & + & + & + \\
\hline $\begin{array}{l}\text { Linanthus bicolor (Nutt.) E. } \\
\text { Greene }\end{array}$ & Annual & Native & + & + & - \\
\hline Lotus humistratus E. Greene & Annual & Native & + & + & + \\
\hline Lotus sp. & Annual & Native & + & + & + \\
\hline Lupinus bicolor Lindley & Annual & Native & + & + & - \\
\hline Madia sp. & Annual & Native & + & + & + \\
\hline $\begin{array}{l}\text { Micropus californicus Fischer \& C. } \\
\text { Meyer }\end{array}$ & Annual & Native & - & + & - \\
\hline Navarretia sp. & Annual & Native & - & + & + \\
\hline Plantago lanceolata $\mathrm{L}$. & Perennial & Introduced & + & - & + \\
\hline Rumex acetosella L. & Perennial & Introduced & + & + & + \\
\hline Sanicula bipinnatifida Hook. & Perennial & Native & - & + & - \\
\hline Sherardia arvensis L. & Annual & Introduced & - & + & - \\
\hline Taraxacum officinale Wigg. & Perennial & Introduced & - & - & + \\
\hline Trichostema lanceolatum Benth. & Annual & Native & + & - & + \\
\hline Trifolium dubium Sibth. & Annual & Introduced & - & - & + \\
\hline Trifolium sp. & Annual & Native & - & + & + \\
\hline $\begin{array}{l}\text { Triphysaria pusilla (Benth.) } \\
\text { Chuang \& Heckard }\end{array}$ & Annual & Native & - & + & - \\
\hline Umbillifer sp. & Perennial & Native & - & - & + \\
\hline Verbena lasiostachys Link. & Perennial & Native & - & - & + \\
\hline Veronica sp. & Annual & Introduced & - & - & + \\
\hline $\begin{array}{l}\text { Yabea microcarpa (Hook \& Arn.) } \\
\text { Koso-Polj. }\end{array}$ & Annual & Native & - & + & + \\
\hline
\end{tabular}

*(rarely includes 1 Brodiaea sp. and 2 Triteleia spp.: see text) 


\section{Figure Legends}

Fig. 1. Proportion of the surface area of five meadows disturbed by pigs. Data represent "recent" damage $(<1$ year old). The number of points sampled on each date from 1991 to 1993 is indicated next to the key. Note that only the White House Meadow was sampled in 1990; the sample size on this date effectively was 2480 points.

Fig. 2. Mean (and standard error, when $\mathrm{n}>1$ ) number of plant species per $25 \mathrm{~cm} \mathrm{x}$ $25 \mathrm{~cm}$ quadrat. These values are minima, since some problematic species may have been pooled; overall, more than 50 species were observed. Sample sizes are indicated above the bars, and for each sampling date, bars designated with different letters differ significantly (t-test or Tukey HSD). Note that no plots in Lower Walker Meadow and only one grubbed plot in Upper Walker Meadow survived by 1993.

Fig. 3. Mean proportion (and standard error, when $\mathrm{n}>1$ ) of plant species per $25 \mathrm{~cm}$ x $25 \mathrm{~cm}$ quadrat contributed by annuals. Sample sizes are indicated above the bars, and for each sampling date, bars designated with different letters differ significantly (t-test or Tukey HSD). Note that no plots in Lower Walker Meadow and only one grubbed plot in Upper Walker Meadow survived by 1993. 


\section{Figure Legends (continued)}

Fig. 4. Mean proportion (and standard error, when $\mathrm{n}>1$ ) of plant species per $25 \mathrm{~cm}$ x $25 \mathrm{~cm}$ quadrat contributed by aliens. In the few cases in which origins were unknown or variable, plants were assigned to categories based on the information available. Sample sizes are indicated above the bars, and for each sampling date, bars designated with different letters differ significantly (t-test or Tukey HSD). Note that no plots in Lower Walker Meadow and only one grubbed plot in Upper Walker Meadow survived by 1993. 